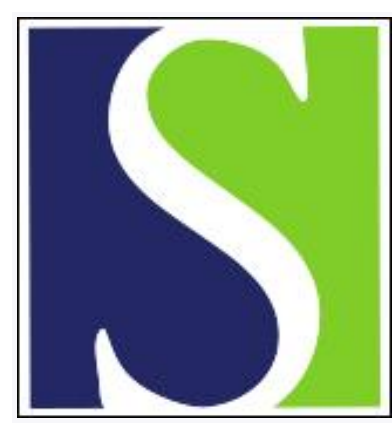

Scand J Work Environ Health 1999;25(1):39-41

https://doi.org/10.5271/sjweh.381

Issue date: Feb 1999

Increase in interleukin-6 and fibrinogen in peripheral blood after swine dust inhalation

by Sjögren B, Wang Z, Larsson B-M, Larsson K, Larsson PH, Westerholm P

The following articles refer to this text: 2002;28(3):205-207;

2004;30(6):438-444

Key terms: endotoxin

This article in PubMed: www.ncbi.nlm.nih.gov/pubmed/10204669

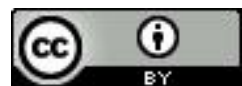




\title{
Increase in interleukin-6 and fibrinogen in peripheral blood after swine dust inhalation
}

\author{
by Bengt Sjögren, MD, ${ }^{1}$ Zhiping Wang, MD, ${ }^{2}$ Britt-Marie Larsson, BSc, ${ }^{2}$ Kjell Larsson, MD, ${ }^{2}$ Per H \\ Larsson, MMedSc, ${ }^{2}$ Peter Westerholm, $M D^{1}$
}

\begin{abstract}
Sjögren B, Wang Z, Larsson B-M, Larsson K, Larsson PH, Westerholm P. Increase in interleukin-6 and fibrinogen in peripheral blood after swine dust inhalation. Scand J Work Environ Health 1999;25(1):39 - 41.

Objectives The inhalation of dust from swine confinement buildings causes inflammatory responses in the airways with a rise of interleukin-6 (IL-6). The purpose of this study was to confirm the increase in serum IL-6 after inhalation of swine dust and investigate a possible increase in plasma fibrinogen.

Methods Eight healthy nonsmoking volunteers inhaled dust for 4 hours inside a swine confinement building. Inhalable dust and endotoxin were sampled. The concentrations of IL- 6 and fibrinogen were determined in serum and plasma.

Results The study showed a clear increase in the concentrations of IL-6 and fibrinogen after exposure.

Conclusions As fibrinogen is an important risk factor for ischemic heart disease, the increased concentration of fibrinogen among persons exposed to swine dust may increase the risk for this disease.
\end{abstract}

Key terms endotoxin.

The inhalation of dust from swine confinement buildings causes inflammatory responses in the airways, bronchial responsiveness, and systemic reactions such as fever and leukocytosis in swine farmers and subjects who have not previously been exposed to farm dust. A rise of interleukin-6 (IL-6) in serum has also been observed (1). IL6 is known to stimulate hepatocytes to secrete fibrinogen (2), and an increased plasma level of fibrinogen is an important risk factor for ischemic heart disease $(3,4)$. An increased risk of ischemic heart disease has also been reported in some studies of farmers $(5,6)$.

The purpose of this study was to confirm the increase in serum IL-6 after the inhalation of swine dust and investigate a possible increase in plasma fibrinogen.

\section{Subjects}

Eight healthy nonsmoking university students ( 3 females) with a mean age of 26 (range 22-31) years participated in the study. All the volunteers passed a health check 2 weeks before the study, including a chest radiograph and blood routine examination. None of them had any allergic symptoms or asthma. None of them had any acute respiratory disease at least 2 weeks prior to the investigation. These volunteers had not been exposed to endotoxin-containing dust in any earlier experiment.

\section{Exposure}

Each subject was exposed for 4 hours while weighing swine in a confinement building containing about 700 pigs, each weighing about $100 \mathrm{~kg}$. The participants assisted the farmer and guided the pigs through weighing boxes. This assistance was associated with a low physical work load.

\section{Methods}

Inhalable dust and endotoxin were sampled at an airflow of $2.0 \mathrm{1} / \mathrm{min}$ for the entire duration of the exposure, using personal samplers with 25-mm IOM (Institute of Occupational Medicine, Edinburgh, Scotland) head openphase filter cassettes and portable pumps (SKC Ltd, Dorset, United Kingdom). The airflow was measured before and after the exposure, and the average value was used

1 Department for Work and Health, Swedish National Institute for Working Life, Solna, Sweden.

2 Department for Occupational Medicine, Swedish National Institute for Working Life, Solna, Sweden.

Reprint request to: Dr Bengt Sjögren, Department for Work and Health, Swedish National Institute for Working Life, S-171 84 Solna, Sweden. [E-mail: Bengt.Sjogren@niwl.se] 
for calculating the volume of sampled air. The cassettes were carried in the breathing zone and were equipped with a $0.4-\mu \mathrm{m}$ polycarbonate filter (Nuclepore Corp, Pleasanton, California, USA). Inhalable dust was measured by weighing after 24 hours of conditioning, using an ME 22 Mettler(®) balance (Mettler, Greisensee, Switzerland) and a reference filter.

The filters used for the endotoxin analysis were extracted in $10 \mathrm{ml}$ of endotoxin-free water. The extracts were centrifuged for 10 minutes, and the supernatants were frozen at $-70^{\circ} \mathrm{C}$ until later analysis with the chromogen version of the Limulus amebocyte lysate assay (QCL-1000, Endotoxin, BioWhittaker, Walkersville, USA).

Blood samples were taken from each subject immediately before the exposure. Samples were also taken 6 and 24 hours thereafter. Samples of serum and plasma were stored at $-70^{\circ} \mathrm{C}$ until the analysis. Each sample underwent only 1 freeze-thaw cycle before being assayed.

IL-6 in serum was determined using commercial ELISA (enzyme-linked immunosorbent assay) kits (R\&D system, British Bio-technology Limited, England). The lowest detectable concentration of IL-6 was $1.5 \mathrm{ng} / \mathrm{l}$.

The plasma was treated with Batroxobin, which cleaves fibrinogen proteolytically. The turbidity developed after the polymerization of the released fibrin monomers and fibrin was measured photometrically by a Hitachi 911 automatic analyzer (Boehringer Mannheim, Germany).

\section{Statistics}

Mean and median values were calculated. Linear regression was used for illustrating the relation between exposure and the concentrations of IL- 6 and fibrinogen. These calculations were performed with StatView for Macintosh.

Table 1. Exposure to dust and endotoxin and concentrations of interleukin-6 in serum and fibrinogen in plasma among 8 volunteers.

\begin{tabular}{|c|c|c|c|c|c|c|}
\hline \multirow[t]{2}{*}{$\begin{array}{l}\text { Volun- } \\
\text { teer }\end{array}$} & \multirow[t]{2}{*}{$\begin{array}{c}\text { Dust } \\
\left(\mathrm{mg} / \mathrm{m}^{3}\right)\end{array}$} & \multirow[t]{2}{*}{$\begin{array}{c}\text { Endotoxin } \\
\left(\mu \mathrm{g} / \mathrm{m}^{3}\right)\end{array}$} & \multicolumn{2}{|c|}{$\begin{array}{l}\text { Interleukin-6 } \\
(\mathrm{ng} / \mathrm{l})\end{array}$} & \multicolumn{2}{|c|}{$\begin{array}{l}\text { Fibrinogen } \\
(\mathrm{g} / \mathrm{l})\end{array}$} \\
\hline & & & $\begin{array}{c}\text { Before } \\
6 \mathrm{~h}\end{array}$ & $\begin{array}{l}\text { After } \\
6 \mathrm{~h}\end{array}$ & $\begin{array}{l}\text { Before } \\
24 \mathrm{~h}\end{array}$ & $\begin{array}{l}\text { After } \\
24 \mathrm{~h}\end{array}$ \\
\hline A & 19.9 & 1.2 & $<1.5$ & 9.7 & 2.97 & 3.86 \\
\hline B & 23.5 & 1.3 & $<1.5$ & 12.4 & 2.63 & 3.97 \\
\hline $\mathrm{C}$ & 18.6 & 0.7 & $<1.5$ & 16.7 & 2.26 & 3.10 \\
\hline $\mathrm{D}$ & 19.9 & 1.2 & $<1.5$ & 11.2 & 2.29 & 3.46 \\
\hline $\mathrm{E}$ & 23.5 & 1.3 & $<1.5$ & 124.3 & 1.78 & 3.09 \\
\hline $\mathrm{F}$ & 18.6 & 0.7 & $<1.5$ & 9.0 & 1.89 & 2.64 \\
\hline G & 11.0 & 0.6 & $<1.5$ & 6.8 & 1.95 & 2.97 \\
\hline $\mathrm{H}$ & 11.0 & 0.6 & $<1.5$ & 17.9 & 1.83 & 3.07 \\
\hline Median & 19.3 & 0.95 & $<1.5$ & 11.8 & 2.11 & 3.10 \\
\hline
\end{tabular}

\section{Results}

The mean inhalable dust exposure was $18 \mathrm{mg} / \mathrm{m}^{3}$, and the mean endotoxin level was $0.96 \mu \mathrm{g} / \mathrm{m}^{3}$. All the assessed concentrations of exposure, as well as the measured levels of IL- 6 and fibrinogen are presented in table 1.

One of the volunteers (D) experienced headache. The temperature of subject $\mathrm{E}$ was $38.2^{\circ} \mathrm{C} 6$ hours after the start of the exposure. Subject $\mathrm{F}$ had a temperature of $38.8^{\circ} \mathrm{C} 12$ hours after the exposure. The blood sample was collected when subject $\mathrm{E}$ had a chill.

The serum levels of IL- 6 were all below $1.5 \mathrm{ng} / \mathrm{l}$ before the exposure, and they increased in all the subjects after the exposure. The median level 6 hours after the beginning of exposure was $11.8 \mathrm{ng} / \mathrm{l}$, which is 7 times higher than the serum concentration before the exposure.

The median increase of fibrinogen in plasma was 51 (range $30-68$ ) \% after 24 hours.

There were positive but statistically nonsignificant correlations ( $\mathrm{r}$ ) between the exposure to dust and the increase in IL-6 $(r=0.43, P=0.29)$ or fibrinogen ( $r=0.19$, $\mathrm{P}=0.65$ ). The relationship was approximately the same regarding the exposure to endotoxin and the increase in IL-6 $(r=0.42, P=0.30)$ and somewhat better regarding the increase in fibrinogen $(\mathrm{r}=0.50, \mathrm{P}=0.21)$. The relationship between the increase in IL- 6 and the increase in fibrinogen was also weak $(r=0.45, P=0.26)$.

\section{Discussion}

The increase in the serum IL-6 concentrations after the inhalation of swine dust and endotoxins confirms the results of a previous study (1). It is notable that the highest plasma level of IL-6 (124.3 ng/1) was associated with fever and a chill. IL-6 is one of several components stimulating hepatocytes to secrete fibrinogen (2). The present study confirms an increase in plasma fibrinogen after IL6 stimulation.

A circadian rhythm has been observed regarding plasma levels of fibrinogen. The highest concentration was seen in the morning, and an approximately $13 \%$ lower level occurred in the evening (7). In this study the fibrinogen samples were taken before the exposure and 24 hours thereafter. Thus diurnal variation was taken into account.

Farmers are exposed to organic dust containing many components, including endotoxin, mites, and molds. This exposure causes allergic and inflammatory respiratory diseases such as asthma, chronic bronchitis, and allergic alveolitis (8).

In a Swedish case-referent study farm managers and supervisors had an increased risk for myocardial 
infarction [RR 1.6, 95\% confidence interval (95\% CI) $1.0-2.6]$, but a similar risk was not observed for agricultural and livestock workers (RR $0.8,95 \%$ CI $0.7-$ 1.0) (5). Finnish female farmers had a significantly higher mean concentration of plasma fibrinogen when compared with white-collar workers. Female Finnish farmers had a higher risk for coronary deaths when compared with white-collar workers (RR 1.7, 95\% CI 1.0-2.8), after adjustment for age, smoking, serum cholesterol, and blood pressure. However, a similar increase was not observed for male farmers (RR $0.9,95 \%$ CI 0.7 to 1.2 ), who had approximately the same levels of plasma fibrinogen as white-collar workers (6).

The dust exposure of the volunteers in the present study was higher than that of swine production workers in the United States (9). The weighing procedure generates more dust as the animals walk from box to box when compared with ordinary days when they move around in one box. Swine confinement workers in the United States were exposed to higher levels of total dust and endotoxin than neighborhood control farmers. Cross-shift changes in lung function were related to exposure to swine confinement work (9). These differences regarding exposure to dusts and endotoxins might be an important factor behind the observed risks regarding ischemic heart disease between different farming populations.

The inhalation of particles and gases from cigarette smoke increases the plasma levels of fibrinogen (10) and the risk for ischemic heart disease (4). However, the increased risk for this disease among smokers is not totally explained by the increased levels of fibrinogen (4).

This relationship between exposure to swine dust and the increase of fibrinogen could be a specific aspect of a theory linking an inflammatory process in the lungs, caused by urban environmental or occupational air pollutants, to the occurrence of ischemic heart disease (11, 12).

\section{Acknowledgments}

The study was approved by the local ethics committee. The study is a part of a large project on work, organization, lipids and fibrinogen (WOLF).
The study was supported by the Swedish Council for Work Life Research and the Swedish Heart Lung Foundation.

\section{References}

1. Wang Z, Malmberg $P$, Larsson $P$, Larsson B-M, Larsson K. Time course of interleukin- 6 and tumor necrosis factor increase in serum following inhalation of swine dust. Am J Respir Crit Care Med 1996;153:147-52.

2. Akira S, Kishimoto T. IL-6 and NF-IL6 in acute-phase response and viral infection. Immunol Rev 1992;127:25-50.

3. Meade TW, Mellows S, Brozovic M, Miller GJ, Chakrabarti RR, North WRS, et al. Haemostatic function and ischaemic heart disease: principle results of the Nortwick Park heart study. Lancet 1986;2:533-7.

4. Yarnell JWG, Baker IA, Sweetnam PM, Bainton D, O'Brien JR, Whitehead PJ, et al. Fibrinogen, viscosity, and white blood cell count are major risk factors for ischemic heart disease. Circulation 1991;83:836-44.

5. Hammar N, Alfredsson L, Smedberg M, Ahlbom A. Differences in the incidence of myocardial infarction among occupational groups. Scand J Work Environ Health 1992;18:17885

6. Jousilahti P, Vartiainen E, Tuomilehto J, Puska P. Occupation, fibrinogen, and heart disease. Lancet 1997;349:506.

7. Haus E, Cusulos M, Sackett-Lundeen L, Swoyer J. Circadian variations in blood coagulation parameters, alpha-antitrypsin antigen and platelet aggregation and retention in clinically healthy subjects. Chronobiol Int 1990;7:203-16.

8. Malmberg P. Health effects of organic dust exposure in dairy farmers. Am J Ind Med 1990;17:7 - 15.

9. Schwartz DA, Donham KJ, Olenchock SA, Popendorf WJ, Van Fossen DS, Burmeister LF, et al. Determinations of longitudinal changes in spirometric function among swine confinement operators and farmers. Am J Respir Crit Care Med 1995;151:47-53.

10. Rosengren A, Wilhelmsen L, Welin L, Tsipogianni A, TegerNilsson A-C, Wedel H. Social influences and cardiovascular risk factors as determinants of plasma fibrinogen concentration in a general population sample of middle age men. BMJ 1990;300:634-8.

11. Seaton A, MacNee W, Donaldson K, Godden D. Particulate air pollution and acute health effects. Lancet 1995;345:1768.

12. Sjögren B. Occupational exposure to dust, inflammation and ishaemic heart disease. Occup Environ Med 1997;54:466-9.

Received for publication: 19 Febrnary 1998 